\title{
Research of personal characteristics of unemployed persons with addictive behavior
}

\section{A. V. Karpov' ${ }^{1}$ M. A. Khors ${ }^{1}$}

${ }^{1}$ P. G. Demidov Yaroslavl State University, 14 Sovetskaya str., Yaroslavl 150003, Russian Federation

DOI: 10.18255/1996-5648-2021-1-92-99

Research article Full text in Russian

The article examines the personal characteristics of unemployed men and women with addictive behavior. In order to determine the personal characteristics of unemployed addicts, the California Psychological Questionnaire CPI was used. The personal characteristics of unemployed addicts are empirically revealed. The differences between unemployed men and women with addicts, as well as the dynamics of the personal characteristics of unemployed people with addictive behavior, due to the age factor, are statistically proved. With age, unemployed people with dependent behavior decrease self-regulation, attention to others, organization, ability to take responsibility for themselves, independence, a tendency to think, insight, and increased rigidity and conservatism.

Keywords: unemployed persons; addictive behavior; personality traits

\section{INFORMATION ABOUT AUTHORS}

\begin{tabular}{l|l} 
Karpov Anatolij V. & $\begin{array}{l}\text { E-mail: anvikar56@yandex.ru } \\
\text { ORCID 0000-0003-4547-2848 } \\
\text { Doc. Sc. (Psychology), Professor }\end{array}$
\end{tabular}

Khors Mikhail A. | E-mail: mkhors@mail.ru

Cand. Sc. degree seeking applicant 


\section{Исследование личностных \\ особенностей безработных лиц \\ с аддиктивным поведением}

\section{А. В. Карпов ${ }^{1}$, M. А. Хорс ${ }^{1}$}

${ }^{1}$ Ярославский государственный университет им. П. Г. Демидова, ул. Советская, 14, Ярославль, 150003, Российская Федерация

DOI: 10.18255/1996-5648-2021-1-92-99

УДК 159.9

Научная статья

Полный текст на русском языке

В статье рассматриваются личностные особенности безработных мужчин и женщин с аддиктивным поведением. С целью определения личностных особенностей безработных аддиктов использовался Калифорнийский психологический опросник СРІ. Эмпирически выявлены личностные особенности безработных аддиктов. Статистически доказаны различия безработных мужчин и женщин - аддиктов, а также динамика личностных характеристик безработных с аддиктивным поведением, обусловленная фактором возраста. С возрастом у безработных с зависимым поведением снижаются саморегуляция, внимание к другим, организованность, способность принимать ответственность на себя, независимость, склонность к размышлениям, проницательность и повышаются ригидность и консервативность.

Ключевые слова: безработные; аддиктивное поведение; качества личности

\section{ИНФОРМАЦИЯ ОБ АВТОРАХ}

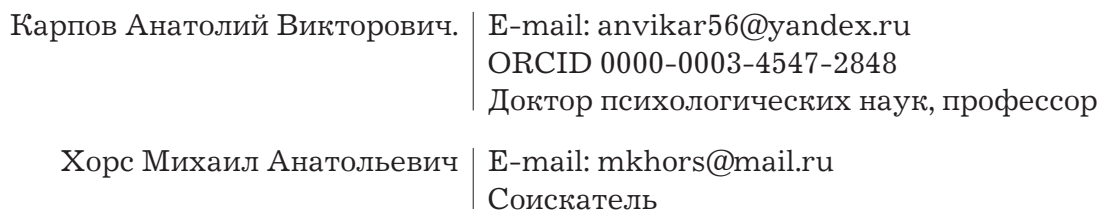

Социально-психологический портрет безработного человека включает в себя множество характеристик. В особую группу можно выделить тех безработных, которые проявляют аддиктивное поведение. В современных исследованиях отдельно рассматривают психологические особенности безработных и особенности поведения и личностные 
Карпов А. В., Хорс М. А.

характеристики лиц, находящихся в поиске работы. Внимание уделяется психологическим, социальным, организационным аспектам профилактики безработицы (Е. В. Борисова, А. Ф. Мещеряков. В. М. Ялтонский, Н. А. Сирота, В. Д. Менделевич и др.).

Однако остаются вне внимания исследователей личностные детерминанты аддиктивного поведения безработных лиц. Актуальность проблемы взаимосвязи формирования аддикций и личностных особенностей бесспорна: она связана с проблемой социальной адаптации, психологической устойчивости и безопасности, жизнестойкости, стрессоустойчивости, развития личностного потенциала. Кроме того, наблюдается противоречие: с одной стороны, отмечается значимость в сознании людей сохранения психического здоровья, здорового образа жизни, с другой представления и знания личности о собственных качествах, затрудняющих личностное развитие, недостаточны для адаптивной психической активности.

С целью определения личностных особенностей безработных аддиктов нами был использован Калифорнийский психологический опросник CPI. Данные подверглись количественному анализу с применением пакета программ («Statistica 20. 0», «MicrosoftExcel»). Оценка статистических различий между группами определялась с помощью непараметрического U-критерия Манна-Уитни. В исследовании приняли участие 330 человек из Москвы и Московской области в возрасте от 22 до 50 лет.

Проведенный анализ качеств личности безработных лиц с аддиктивным поведением выявил следующее. В наибольшей степени проявляются особенности самовосприятия. Безработный человек с аддиктивным поведением не может определить уникальные черты, которые бы отличали его от других людей (шкала «Обычность» $(\mathrm{Cm})$. Испытуемые не признают в себе личность, которая обладает какими-либо талантами или способностями. При описании собственной деятельности они не могут точно определить свои интересы, отмечают общую жизненную неустроенность, разделяют жизнь реальную и образ себя как активную личность, демонстрируют неуверенность в себе.

Для безработных с аддиктивным поведением характерны низкий уровень рефлексии или ее отсутствие, нечеткость смысложизненных ориентаций. Учитывая мнение исследователей о том, что рефлексивные способности являются базовым конструктом регулятивных характеристик личности [1-2], можно утверждать, что самоконтроль действий и поведения безработного с аддиктивным поведением снижен из-за позитивного самооценивания, использования собственного образа как са- 
моподкрепления, а представление себя «обычным» снижает целенаправленность личности, его мотивацию к достижению успеха.

Другой доминирующей характеристикой является проявление черт личности, выраженных по шкале «Социальное присутствие» (Sp): выделяются демонстративность, стремление к власти и манипуляциям во взаимодействии с другими, низкая коммуникативность, спонтанность действий и поступков. Можно предположить, что безработный аддикт воспринимает окружающую действительность как угрожающую, что приводит к возникновению стремления к власти как реакции на неизвестность ситуации, желание защититься от воспринимаемых угроз внешнего мира. В сущности, стремление к власти у безработных с аддиктивным поведением является особой фрормой приспособления к миру, к выживанию в нем, выступает своего рода компенсацией фррустрации, в некоторых случаях - чувства ущербности и личностной несостоятельности.

Третьим по уровню проявления являются качества, выраженные по шкале «Общительность» (Sy). В связи с тем, что высокие показатели по данной шкале свидетельствуют об ориентации личности на общение, они более чувствительны к социально депривационным явлениям, которые, как правило, характерны для безработных. Среди причин депривации как особого психического состояния личности исследователи выделяют следующие: несоответствие между социально желаемой реакцией и подкрепляющим ее стимулом, неудовлетворенность социальных потребностей (в эмоциональных контактах, принятии со стороны других, сочувствии, сопереживании), неопределенность ценностей и мотивов личности [3]. Очевидно, что противоречия между стремлением к общению, пониманию и недостаточно полным взаимодействием с другими становится барьером для преодоления аддикций у безработного, фрормирования уверенности в себе, переживания ценности собственной личности. Лица, чьи потребности в качественном взаимодействии, уважении со стороны других находятся в противоречии с возможностями среды их удовлетворить, склонны психологически защищаться с помощью ухода в воображаемый мир, франтазии, разных фрорм аддиктивного поведения.

Четвертым по уровню проявления качеством выявлена эмпатическая способность - шкала «Эмпатия» (Em). Это означает, что безработные с аддиктивным поведением обладают способностями в понимании установок, мыслей, чувств других людей, являются восприимчивыми к различным проявлениям социально-коммуникативного взаимодействия. На наш взгляд, эмпатичность может стать тем личностным ресурсом, 
Карпов А. В., Хорс М. А.

который позволяет безработному преодолевать негативные проявления аддиктивного поведения (агрессию, сниженную коммуникацию и др.). С другой стороны, люди с высоко развитой эмпатией в большей степени, чем другие, способны чувствовать угрозы внешней ситуации, агрессивную атмосферу.

Эмпирические данные показывают, что безработные аддикты проявляют импульсивность, склонны к поверхностным суждениям, к неустойчивости в афрективных проявлениях, к повышенной динамике эмоций, эгоцентричны, стремятся к сиюминутному удовлетворению потребностей. В отношениях с другими людьми нестабильны, проявляют склонность к быстрой смене партнеров по общению. У них выявлена ригидность, склонность к рискованному поведению, упрямству. В работах отечественных авторов склонность к риску зачастую связывают с положительным отношением к себе, с принятием себя и уверенностью в себе, с доверием к окружающему миру [4]. Однако надо отметить, что качество склонности к риску не всегда является осмысленной и контролируемой деятельностью. Можно предположить, что у безработных с аддиктивным поведением данное качество в наибольшей степени отражает повышенную склонность человека к поиску ощущений, возбуждения, приключений.

Что касается высокого показателя по качеству «ригидность», то можно утверждать, что наблюдения в диагностической беседе также выявили низкий уровень способности переключаться с одного объекта на другой, переходить от одного способа действия к другому. Ригидность безработного аддикта проявляется в низко развитой способности человека изменять представления о себе и других, что не позволяет ему успешно адаптироваться в изменяющихся условиях жизнедеятельности. То, что ригидность является значимым фрактором социальной дезадаптации, подтверждено рядом исследований [5-7] и еще раз подчеркивает значимость включения в процесс психологического консультирования активизации когнитивных процессов, отвечающих в наибольшей степени за способы реагирования на различные ситуации, сопротивляться негативным проявлениям, связанным с аддикциями.

Согласно данным, полученным по шкале «Толерантность» (То), у испытуемых проявляются следующие качества: низкий уровень развития качеств, способствующих коллективной деятельности (сотрудничество, взаимопонимание, оптимальное решение конфрликтных ситуаций и т. п.), а также авторитарность, враждебность, склонность к осуждению других. 
Безработные с аддикциями склонны проявлять консервативность, они не уверены в собственных возможностях (шкала «Достижение через независимость» (Ai). Для них характерны недипломатичность, критичность, резкость, как правило, невоспитанность (шкала «Хорошее впечатление» (Gi).

Сравнительный анализ данных мужчин и женщин показал, что безработные женщины-аддикты в меньшей мере, чем мужчины-аддикты обладают познавательной активностью, изобретательностью,

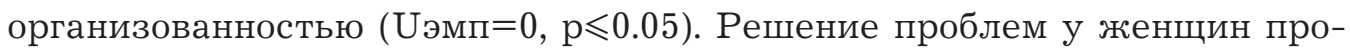
исходит без планирования действия, спонтанно. Безработные женщины, имеющие зависимости, характеризуются высокой тревожностью и склонностью к депрессии.

По шкале «Толерантность» (То) у женщин в большей степени выражена конфликтность, конфронтация, подозрительность по отношению к другим, недоверчивость, враждебность; в меньшей - стремление к сотрудничеству, работе в команде.

По шкале «Психологический склад ума» (Ру) выявлены различия в следующих качествах личности: женщины в большей степени стремятся перекладывать ответственность на других людей по сравнению с мужчинами, в определении сути проблемы более поверхностны, в меньшей степени стремятся понять мотивы других.

Выявлены значимые различия психологических характеристик безработных с аддиктивным поведением разного возраста ( $\left.\mathrm{U}_{\text {эмп }}=0, \mathrm{p} \leqslant 0.05\right)$. Так, согласно эмпирическим данным первой группы шкал (Do, Cs, Sy, Sp, $\mathrm{Sa}, \mathrm{In}, \mathrm{Em})$, безработные до 30 лет отличаются меньшей уверенностью в себе. Данные второй группы шкал (Re, So, Sc, Gi, Cm, Wb, To) показывают низкую личностную зрелость у безработных до 30 лет, склонность к неоправданному риску, низкие прогностические способности относительно своих действий и недостаточный самоконтроль.

Наиболее низкие баллы у безработных до 30 лет по сравнению с другими возрастными группами по третьей группе шкал (Ac, Ai, Ie) свидетельствуют об их склонности при преодолении сложных ситуаций прибегать к психологическим защитам, быть крайне осторожными в различных ситуациях жизнедеятельности.

По четвертому классу шкал (Рy, Fx, Fe/m) значимых различий не выявлено. Исследование показало, что все испытуемые имеют слабую заинтересованность в своем изменении, низкий уровень мотивации к интересам других людей, не склонны уделять внимание своему положению в обществе и отношениям к себе других лиц (Ру). У всех испытуемых 
Карпов А. В., Хорс М. А.

выявлена высокая ригидность, консервативность, трудности адаптации к переменам (Fx). Они могут проявлять нетерпимость по отношению к другим, находятся в эмоциональной зависимости от собственных действий, проявляют агрессию.

Отличительными характеристиками безработных от 31 до 40 лет являются следующие. Они в меньшей степени, чем лица более старшего возраста, настойчивы, активны, испытывают стремление влиять на других людей (Sp). Показывают более высокий уровень конфликтности, самообвинения, чувства вины по сравнению с лицами других возрастных групп (Sa). Выявлены значимые различия по шкалам «Ответственность» $(\mathrm{Re})$ и «Интеллектуальная эфрфективность» (Iе), которые свидетельствуют, что у безработных с аддикциями в этом возрасте в большей степени по сравнению с более старшими лицами проявляются импульсивность, неорганизованность, недисциплинированность, эгоцентричность. При этом они не берут на себя ответственность, что свидетельствует о высоком уровне экстернального локуса контроля. Они не доверяют своим интеллектуальным способностям, у них в большей степени развито репродуктивное мышление, чем творческое, они практичны в подходах к решению проблем.

Отличительными характеристиками безработных с аддиктивным поведением от 41 до 50 лет являются ярко выраженные черты, соответствующие шкалам «Социальное присутствие» ( $\mathrm{Sp})$, «Самоприятие» (Sa), «Обычность» $(\mathrm{Cm})$. Это означает, что они в большей степени по сравнению с другими безработными аддиктами стремятся к признанию, демонстративности, самоутверждению. В большей степени по сравнению с другими способны регулировать свои эмоции и поведение, брать ответственность за собственные действия.

Выявлена динамика личностных характеристик безработных с аддиктивным поведением, обусловленная фрактором возраста по следующим шкалам: “Ответственность» (Re), «Самоконтроль» $(\mathrm{Sc})$, «Достижение через независимость» (Ai), «Интеллектуальная эффективность» (Ie). С увеличением возраста у безработных с зависимым поведением понижается саморегуляция, внимание к другим, организованность, способность принимать ответственность на себя, независимость, склонность к размышлениям, проницательность. При этом с возрастом повышается ригидность и консервативность.

\section{Выводы}

1. Анализ теоретических положений по проблеме исследования показывает, что личностные особенности безработных лиц исследуются 
с точки зрения возможности их социальной и профессиональной адаптации. Однако недостаточно работ, раскрывающих индивидуально психологические качества безработных с аддиктивным поведением;

2. Эмпирически выявлены личностные особенности безработных аддиктов. Статистически доказаны различия безработных мужчин и женщин - аддиктов, а также динамика личностных характеристик безработных с аддиктивным поведением, обусловленная фрактором возраста.

\section{Ссылки}

1. Карпов А. В. Психология рефлексивных механизмов деятельности. М.: ИП РАН, 2004. $428 \mathrm{c}$.

2. Перевозкина Ю.М.,Спирин А.В.,Федоришин М.И.Ценностно-рефлексивные детерминантысаморегуляциикурсантоввойскнациональнойгвардииРоссийской Федерации // Вестник Ярославского государственного университета им. П. Г. Демидова. 2020. № 2(52).С. 106-113.

3. Клейберг Ю. А. Социальная неопределенность личности как фрактор девиантного поведения // Историко-критические обзоры и современные исследования. 2015. № 4-5. С. 8-17.

4. Тенденции развития современной психологической науки / отв. ред. А. Л. Журавлев, В. А. Кольцова. М.: ИП РАН, 2007. Ч. І. 428 с.

5. Клейберг Ю. А. Девиантология: хрестоматия. СПб: Речь, 2007. 412 с.

6. Овчарова Е. В. Психологические особенности безработных в зависимости от стажа безработицы // Вестник государственного Ярославского университета им. П. Г. Демидова. Серия Гуманитарные науки. 2012. № 4(22). С. 103-106.

7. Плюснин Ю. М., Пошевнев П. С. Социальная психология безработного. Новосибирск: ЦСА,1997.84 с. 